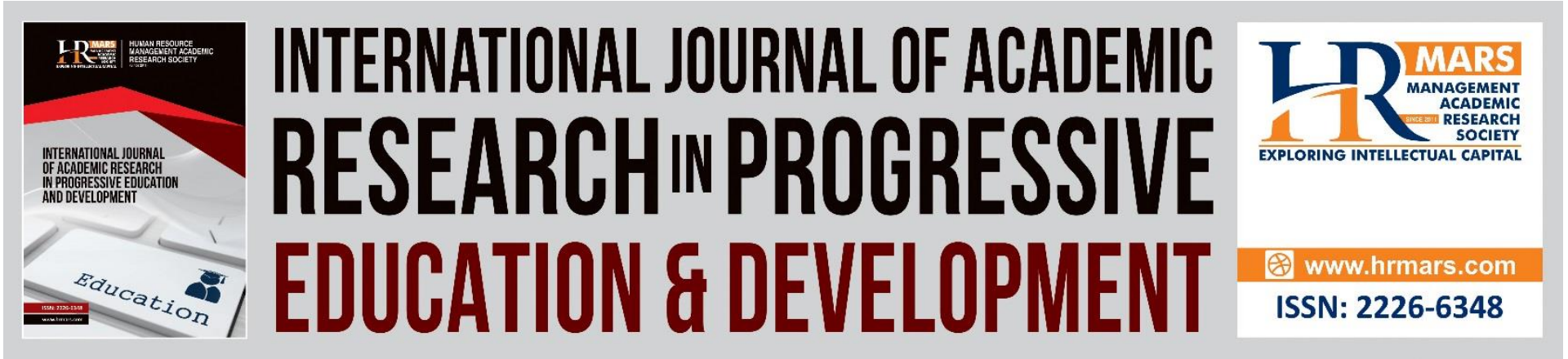

\title{
Obesity as A Risk Factor for Hypertension
}

\section{Yahya Fahim}

To Link this Article: http://dx.doi.org/10.6007/IJARPED/v10-i2/10680

Received: 07 May 2021, Revised: 11 June 2021, Accepted: 16 June 2021

Published Online: 22 July 2021

In-Text Citation: (Fahim, 2021)

To Cite this Article: Fahim, Y. (2021). Obesity as A Risk Factor for Hypertension. International Journal of Academic Research in Progressive Education and Development, 10(2), 1104-1109.

\footnotetext{
Copyright: (C) 2021 The Author(s)

Published by Human Resource Management Academic Research Society (www.hrmars.com)

This article is published under the Creative Commons Attribution (CC BY 4.0) license. Anyone may reproduce, distribute, translate and create derivative works of this article (for both commercial and non-commercial purposes), subject to full attribution to the original publication and authors. The full terms of this license may be seen

at: http://creativecommons.org/licences/by/4.0/legalcode
}

\section{Vol. 10(2) 2021, Pg. 1104 - 1109}

Full Terms \& Conditions of access and use can be found at http://hrmars.com/index.php/pages/detail/publication-ethics 


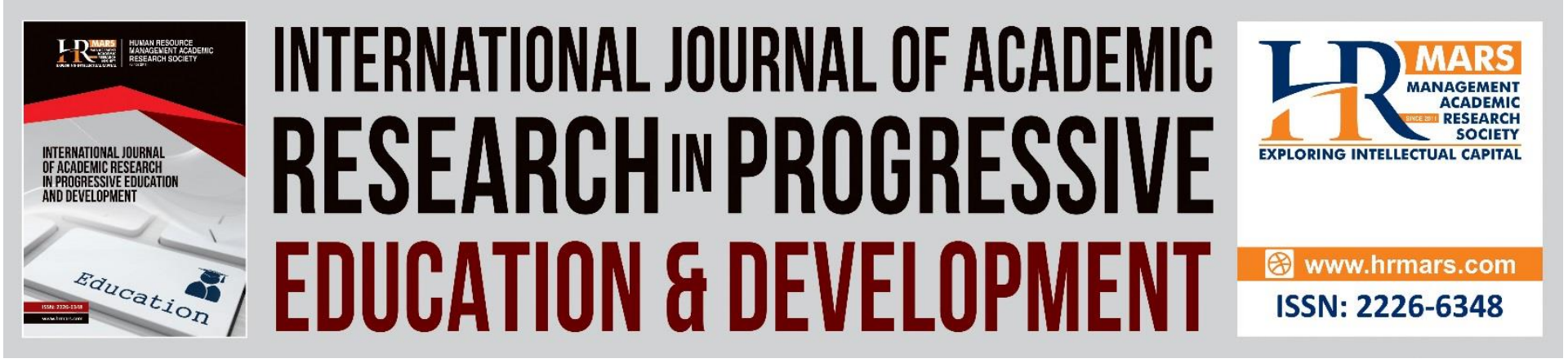

\title{
Obesity as A Risk Factor for Hypertension
}

\author{
Yahya Fahim \\ Assistant professor Department of Biochemistry, Faculty of Medical, Nangarhar University, \\ Afghanistan \\ Email: fahim_icc@yahoo.com
}

\begin{abstract}
Obesity has been a considered as phenomenon around the globe, leading to a variety of disorders such as metabolic diseases, asthma, and cardiovascular disease. Obesity and overweight are often related to increased levels of aldosterone in the blood, which implies a direct relationship between obesity, high blood pressure and mineralocorticoid levels. Adipocyte is believed to have a part in the fight against homeostasis, and recent studies have now shown that human fat is a highly active endocrine tissue. The research thus examined whether obesity is a rik factor for hypertension. The steroid genesis in human adrenocortical cells, $\mathrm{NCl}-\mathrm{H} 295 \mathrm{R}$ and bovine adrenocortical cells, was increased by isolation of human adicyte secretion products, focusing on the secretion of mineral corticoids. The outcoems indidcated that hypertension associated to obesity has direct relation between the metabolism of fat tissue and the production of adrenal mineralocorticoids.
\end{abstract}

Keywords: Obesity, Hypertension, Risk

\section{Introduction}

Obesity, particularly visceral obesity, is significantly linked to high blood hypertension. It was established by a diverse range of ethnic, religious, and socioeconomic peoples and is not limited to developed countries (Ashley, 2010; Bouchard, 2009). The link between obesity and high hypertension has long been acknowledged, but the molecular basis for the connection between obesity and high hypertension remains a mystery.

Hyperaldosteronism is frequently linked to obesity (Drenick \& Johnson, 2013), and plasma aldosterone levels are compared with fatty tissue volume (Blair et al., 2007). The aldosterone mineralocorticoid is the strongest adrenal cortex produced mineralocorticoid which helps salt buildup and blood pressure. A causal connection between high blood aldosterone levels and hypertension in obese individuals was therefore suggested (Contreras et al., 2004). Surprisingly, the increase of aldosterone in obesity is frequently independent to the activity of the plasma renin. The same applies to our own results, in which the obese, normotensive (RR 130/80, $n=16$ ) individuals were shown to have a somewhat higher aldosterone/renine ratio ( $R R>145 / 95, n=16)$.

For a long time, white adipose tissue was only thought of as a source of lipids and thus an energy source. Adipose tissue has just lately been identified as a endocrine organ with a high rate of activity and its role in metabolic and homeostatic regulation (Crepaldi et al., 2015). We 
have investigated the assumption that human adipocyte secretary products are accountable for obesity-relationship dysfunctions of suprarenal steroids, particularly an increased mineral corticoids secretion. by directly affecting adrenal cortical activity.

\section{Materials and Methods}

\section{Human Tissues}

The stable ladies (twenty to thirty-five years old) who have had surgical mammal reductions $(n=10)$ provide the human adipose tissue specimens. Collagenase digestion has been used to separate adipocytes, as previously mentioned (Drewnowski \& Holden-White, 2007). In isolated, floating adipocyte serum-free conditions, DMEM/F12 with $15 \mathrm{mmol} / \mathrm{I} \mathrm{HEPES}$ and 2,5 $\mathrm{mmol} / \mathrm{l} \mathrm{L}$-glutamine, $1.125 \mathrm{~g} / \mathrm{l} \mathrm{NaHCO}, 100 \mathrm{U} / \mathrm{ml}$ penicillin, and $100 \mathrm{mg} / \mathrm{ml}$ Streptomycin were grown. Cells were cultivated in a humidified environment with $5 \% \mathrm{CO} 2$ for twenty four hour at $37^{\circ} \mathrm{C}$. The conditioned medium was carefully collected to ensure that the lipid did not float to the top.

\section{Adrenocortical Cells}

The bovine adrenal in a local slaughterhouse was acquired in Nangarhar, Afghanistan and trypsin-digested adrenal cell was used for 3-4 days to cultivate a confluence of 70 percent in DMEM/F12 (14). NCl-H295R adrenocortical (ATCC) cells were grown using DMEM/F12 (Hamm et al., 1989).

\section{Adrenocortical Cells Incubation}

For twenty four hours, $\mathrm{NCl}-\mathrm{H} 295 \mathrm{R}$ or adrenocortical bovine cells were cultured serum-free in fat-conditioned media. FCCM was combined with ascorbic acid $(20 \mathrm{mg} / \mathrm{ml})$, bovine transferin $(10 \mathrm{mg} / \mathrm{ml})$, bacitracin $(100 \mathrm{mg} / \mathrm{ml})$, penicillin $(100 \mathrm{U} / \mathrm{ml})$, streptomycin $(100 \mathrm{mg} / \mathrm{ml})$ and gentamycin $(50 \% \mathrm{mg} / \mathrm{ml})$ for the incubation of adrenocoretic bovine cells. $\mathrm{NCl}-\mathrm{H} 295 \mathrm{R}$ cells were treated with FCCM insulin $(52 \mathrm{nM})$, hydrocortisone $(10 \mathrm{nM})$, b-estradiol $(10 \mathrm{nM})$, transferrin $(10 \mathrm{mg} / \mathrm{ml})$, Selenite $(30 \mathrm{nM})$ and penicillin $(1100 \mathrm{U} / \mathrm{ml})$. After incubation and before to analysis, the medium was collected and frozen at $20^{\circ} \mathrm{C}$. A direct radioimmunoassay was used to measure the concentration of aldosterone in the incubation medium (Han, and Lean, 2015).

\section{Results and Discussion}

According to our results, human adipocytes produce strong release factors. Fat cell-derived secretagogs induced adrenocortical steroidosis with the main impact on aldosterone release in human cells $\mathrm{NCl}-\mathrm{H} 295 \mathrm{R}$. (Fig. 1).
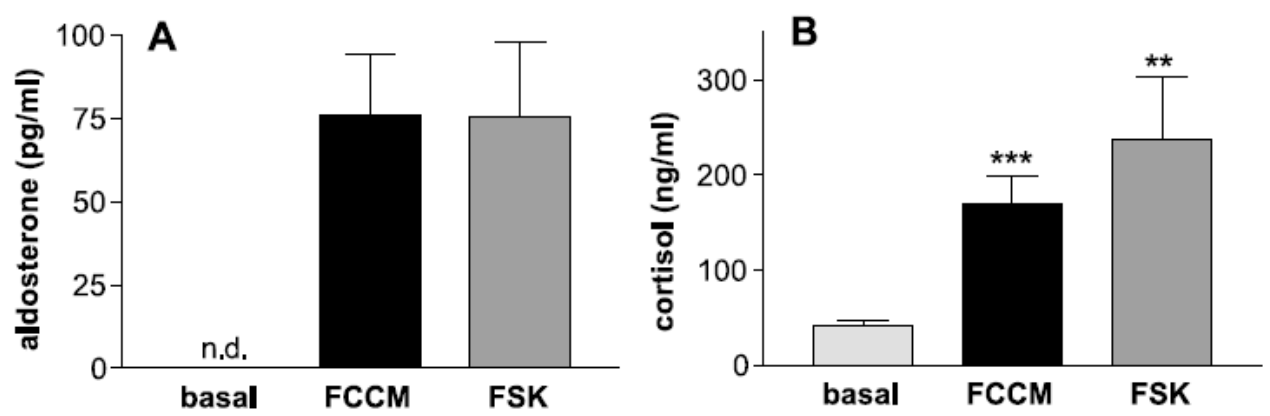

Figure 1. Secretion of aldosterone (A) and cortisol (B) from NCI-H295R cells 
This is recently confirmed in primary culture in bovine adrenocortic cells when fat-cell medial (FCCM) is compared with the maximum forskolin stimulation 210-5M (FSK). 24 h. n.d.: nondetectable cells were cultured. Mean \pm SEM, $n=$ four different preparations for fat cells, four wells / experiment. Important differences in basal secretions are: $p<0.001\left(^{* * *}\right), p<0.01\left({ }^{* *}\right)$. [Eng-Hen et al., 1997).
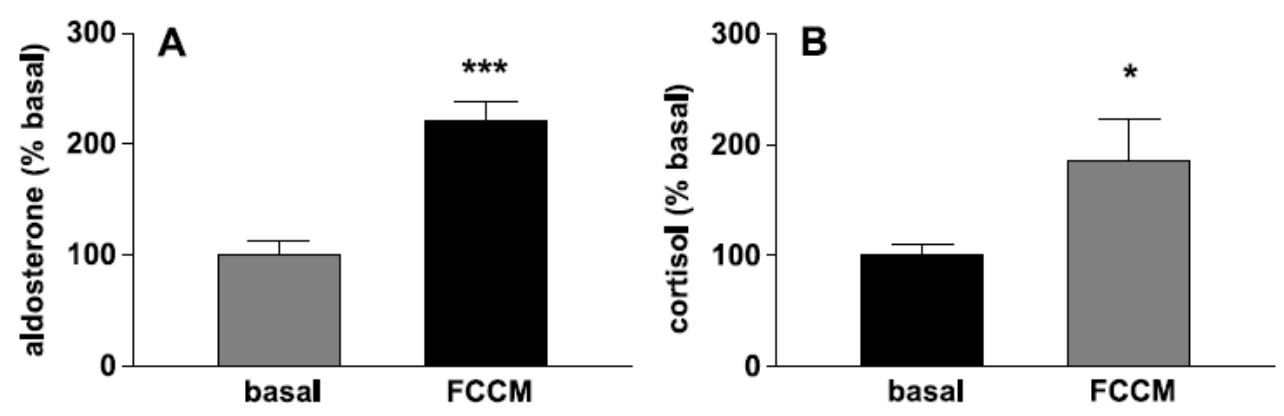

Figure 2. Secretion of aldosterone (A) and cortisol (B) from bovine adrenocortical Primary culture cells after fat cell-conditioned media stimulation (FCCM). $24 \mathrm{~h}$ cells have been incubated. Mean \pm SEM, $\mathrm{n}=6$ different tests, 4 wells/experiment. Important basal secretion differences are shown: $p<0.001\left({ }^{* * *}\right), p<0.01\left(^{*}\right)$. FCCM incubation, albeit to a lower extent than in H295R cells, encouraged aldosterone and cortisol production (Fig. 2). The adipose tissue produces angiotensinogen and angiotensin II in significant amounts. Fatcell-conditioned medium stimulant activity (FCCM) also demonstrated an independent impact of an adipose angiotensin II Valsartan is used in the presence of an Angiotensin type 1 receptor antagonist. Factor-a may also be excluded from obesity, like lepin, adiponectin, interleukine-6, and tumor necrosis (Hanson et al., 2014). The stimulating effect corresponded to the maximum stimulation of forskolin (Fig. 1). The activity was thermal, ammonium sulfate may be precipitated and protease digested, indicating the protein involved. Adipocytes also disclose at least two substances, which work together to boost aldosterone secretion (Haus et al., 2017). These results indicate that adipose tissue has an undiscovered direct involvement in the adrenocortics, particularly in the production of mineralocorticoids.

How do the substances secreted by adipocytes make their way to the adrenal cortex? Several adipocyte secretory products have an auto/paracrine effect on adipocyte metabolism. However, many reasons are released and evaluated in the bloodstream (Han, and Lean, 2015). The adrenal and adrenocortical steroidosis produce an endocrine adrenal steroid in the circulation secretion from subcutaneous or visceral fat. In addition, in close contact with steroidal cells, fat cells are frequently present in the adrenal. Direct paracrine associations and potential steroidogenesis stimulation by adipocyte secretory products are made possible by this near cellular proximity.

Our study described an instance of intraadrenal myelolipoma in a patient with Cushing's disease that is not reliant on ACTH (Bennet, 2015), which included a significant proportion of myelolipomatous and adrenocortical tumor cells with abundant clear cell-cell contact (Fig. 3). Myelolipoma cell secretion products' paracrine actions are believed to be responsible for this patient's elevated cortisol production.

We thus propose that mineralocorticotropic adipocyte factors may increase endocrine or paracrine aldosterone production and secretion leading to hyperaldosteronism and, as a 
consequence, obesity hypertension. This indicates that the fat cell mass and the blood pressure are clearly linked. Discovery of these reasons and subsequent characterization may lead to novel treatment options for hypertension associated with obesity.

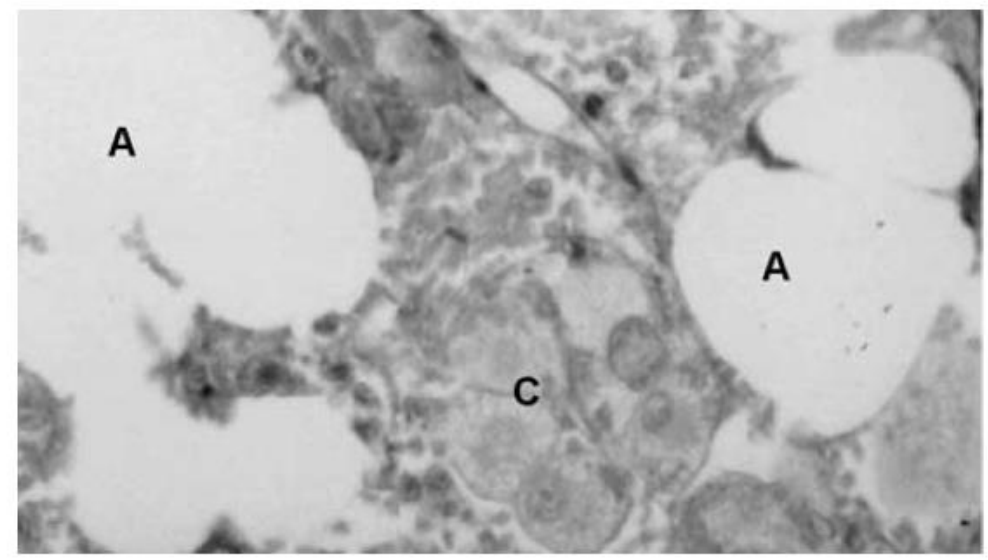

Figure 3. Paraffin section of a human adrenal from a patient with intraadrenal myelolipoma. Adipocytes (A) in direct contact with adrenocortical cells (C) within the adrenal.

\section{References}

Ashley, F. W., \& Kannel, W. B. (1974). Bodyweight, health and longevity. J. Intern. Med. 27, $103-114$.

Bennet, W. (1987). Dietary treatments of obesity. In: Human Obesity, ed. RJ Wurtman \& JJ Wurtman. Annals of the New York Academy of Science. New York 49 (5), 250 - 263.

Blair, S. N., Shaten, J., Brownell, K. D., Collins, G., \& Lissner, L. (1993): Body weight change, allcause and cause-specific mortality in the Multiple Risk Factor Intervention Trial. Ann. Intern. Med. 119, 749 - 757.

Bouchard, C. (1991). Is weight fluctuation a risk factor? New Engl. J. Med. 324, 1887 - 1889.

Contreras, R. J., King, S., Rives, L., Williams, A., \& Wattleton, T. (1991). Dietary obesity and weight cycling in rats: a model of stress-induced hypertension? Am. J. Physiol. 21(6), 848 - 857.

Crepaldi, G., Belore, F., Bosello, O. N. (1991). Italian consensus conference overweight, obesity and health. Int. J. Obes. 15 (3), 781 - 790.

Drenick, E. J., \& Johnson, D. (1978). Weight reduction by fasting and semistarvation in morbid obesity: long-term follow-up. Int. J. Obes. 2 (7), 123 - 132.

Drewnowski, A., \& Holden-White, J. (1992). Taste responses and food preferences in obese women: effects of weight cycling. Int. J. Obes. 16 (6), 639 - 648.

Eng-Hen, N. G., Fei, G., Chen-Yang, J. I., Gay-Hui, H. O., \& Khee-Chee, S. O. (1997): Risk factors for breast carcinoma in Singaporean Chinese women. The role of central obesity. Cancer 80, $725-731$.

Hamm, P., Shekelle, R. B., \& Stamler, J. (1989). Large fluctuations in body weight during young adulthood and twenty-five-year risk of coronary death in men. Am. J. Epidemiol. 12(9), 312 - 318.

Han, T. S., and Lean, M. E. J. (1995). Waist circumference action levels in the identification of cardiovascular risk factors: prevalence study in a random sample. Br. Med. J. 31(11), 1401 - 1405. 
Hanson, R. L., Jacobsson, L. T., \& Knowler, W. C. (1996): Weight fluctuation, mortality and vascular disease in Pima Indians. Int. J. Obes. 20(9), 463 - 471.

Haus, G., Hoerr, S. L., Mavis, B., \& Robison, J. (1994). Key modifiable factors in weight maintenance: fat intake, exercise, and weight cycling. J. Am. Diet. Assoc. 94, 409 - 413.

Hudgins, L. C., \& Hirsch, J. (1991). Changes in abdominal and gluteal adipose tissue fatty acid compositions in obese subjects after weight gain and weight loss. Am. J. Clin. Nutr. 53(12), 1372 - 1377.

Jeffery, R. W., Wing, R. R., \& French, S. A. (1992). Weight cycling and cardiovascular risk factors in obese men and women. Am. J. Clin. Nutr. 55, $641-644$.

World Health Organization. (1998). Obesity: preventing and managing the global epidemic. Geneva: Report of a WHO Consultation on Obesity. 